\title{
Physical Activity and Sports Practice in Children and Adolescents at the Time of the COVID-19 Pandemic: Hypothetical Future Scenarios and Preventive Practical Applications
}

\author{
Giuseppe Battaglia *(D) and Antonio Palma
}

Department of Psychology, Educational Science and Human Movement, University of Palermo, Via Giovanni Pascoli 6, 90144 Palermo, Italy; antonio.palma@unipa.it

* Correspondence: giuseppe.battaglia@unipa.it

check for updates

Citation: Battaglia, G.; Palma, A. Physical Activity and Sports Practice in Children and Adolescents at the Time of the COVID-19 Pandemic: Hypothetical Future Scenarios and Preventive Practical Applications. Sustainability 2021, 13, 13787. https:/ / doi.org/10.3390/su132413787

Received: 30 November 2021 Accepted: 8 December 2021

Published: 14 December 2021

Publisher's Note: MDPI stays neutral with regard to jurisdictional claims in published maps and institutional affiliations.

Copyright: (c) 2021 by the authors. Licensee MDPI, Basel, Switzerland. This article is an open access article distributed under the terms and conditions of the Creative Commons Attribution (CC BY) license (https:// creativecommons.org/licenses/by/ $4.0 /)$.
Abstract: As a logical and direct consequence of the closure of schools and sports facilities, an expected reduction in the practice of physical activity (PA) and sports has been detected in both children and adolescents all over the world. Hence, we analysed the short-term and long-term consequences of the lack/low level of PA and sports activity in this population, which we referred to as primary and secondary risks, respectively, the latter of which have to be considered in hypothetical future scenarios.

Keywords: COVID-19; coronavirus; physical activity; sport; children; adolescents

\section{Introduction}

Since December 2019, humanity has been affected by a severe acute respiratory syndrome with unknown origin, caused by a novel coronavirus named SARS-CoV-2, the coronavirus disease-2019 (COVID-19) [1]. Due to rapid worldwide transmission, the World Health Organisation (WHO) declared the COVID-19 a global pandemic in March 2020 [2].

In order to contain the spread of the virus and prevent the contagion, the governments of each country have adopted restrictive and precautionary measures known as nonpharmaceutical interventions (NPIs), forcing humans to change their lifestyle [3-5], and therewith scientists have developed models to predict the effectiveness of different NPIs [6]. Among the NPIs, a significant impact on society has been given by the closure of schools and sports facilities, in an attempt to keep people at home as much as possible [7-10]. As a logical and direct consequence, an expected reduction in the practice of physical activity (PA) and sports has been detected in both children and adolescents all over the world [11,12].

\section{Impact of COVID-19 on PA and Sports Activity: Short- and Long-Term Consequences}

The decrease in PA/sports practice and the increase in sedentary behaviour, as has been occurring since the onset of the pandemic to date, represents a critical issue for the population and particularly alarming for children and adolescents [13]. In fact, the fundamental role of PA and sports in numerous aspects related to mental and physical health during development is widely recognised [11].

Due to the current context, the lack/low level of PA and sports activity can lead to serious short- and long-term consequences, which we referred to as primary and secondary risks, respectively (Figure 1). Although the primary risks have been extensively investigated, the secondary risks have to be considered in hypothetical future scenarios. 


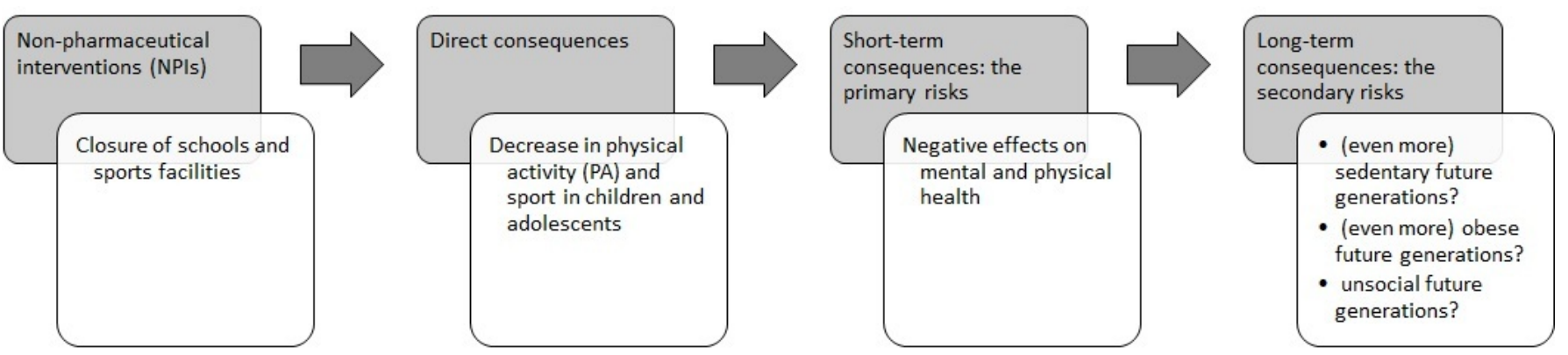

Figure 1. From the closure of schools and sports facilities to hypothetical future scenarios.

\section{Short-Term Consequences: The Primary Risks}

The lack of physical education and after-school sports activities can lead to early negative effects on both mental and physical health in children and adolescents $[11,14,15]$.

Regarding the mental sphere, recent findings have shown an increase in anxiety and depression in adolescent athletes [15], as well as suicide behaviours linked to the COVID-19 pandemic [16]. Other psychosocial manifestations such as distress, impatience, annoyance, and lack of social interactions may be related to the closure of schools and the lack of PA due to the current pandemic [14].

As regards the physical characteristics, the main short-term consequence of the lack/low level of PA and sports activity is linked to the risk of overweight and obesity, accompanied by a reduction in lean body mass [17]. This is also due to the fact that children with a sedentary lifestyle engage in harmful behaviour (for example, eating unhealthy foods) [18].

\section{Long-Term Consequences: The Secondary Risks-What Hypothetical Future Scenarios?} 4.1. Sedentary Behaviour

Although there are differences between genders and countries, the increase in sedentary behaviour and insufficient levels of PA represent a global prevalence in all ages, including children and adolescents, with a rate of $81 \%$ of adolescents aged between 11 and 17 years $[13,19]$. To counteract this serious health problem, the WHO has recently developed guidelines on physical activity and sedentary behaviour for children and adolescents providing recommendations concerning the type of physical activity and the associated parameters (i.e., intensities, frequencies, and durations) [20].

As health behavioural patterns (such as physical inactivity and sedentary behaviour) adopted during the developmental age appear to persist throughout life [21], in this protracted pandemic-related context, do we risk having (even more) sedentary future generations?

\subsection{Overweight and Obesity}

It is now known that the rates of overweight and obesity in childhood are constantly increasing and the practice of PA and sports can counteract this critical health problem. Moreover, it plays a fundamental role in preventing the development of overweight and obesity in adulthood [22-24]. Evidence suggests that even during the summer recess, when schools are closed, children gain unhealthy body weight [25]. Due to the current situation in which opportunities for PA and sports activity among children have declined over a long period, do we risk having (even more) obese future generations?

\subsection{Social Interactions}

The practice of PA and sports has beneficial effects on psychophysical characteristics and also positively influences the social domain. Social benefits, such as self-esteem and life satisfaction, in children and adolescents through participation in PA and sports are well documented [26]. Since the NPIs, such as the closure of schools and sports facilities, have 
reduced the habitual PA and sports practice and the related social interactions, do we risk having unsocial future generations?

\section{Preventive Practical Applications}

To cope with the current emergency in terms of diminished levels of curricular and extracurricular PA and sports practice, adapted strategies should be adopted. Among the latter, we strongly recommend home-based exercise using communication platforms for videoconferencing by physical education teachers, sports technicians, and trainers in order to maintain an active lifestyle during the COVID-19 pandemic. Additionally, other social media platforms could be used to propose physical challenges in short-form videos. More recently, apps for mobile devices have been developed for practicing physical activity from home [27]. The latter mode, even if it does not allow a constant and direct control by a trainer, can still be useful support for the general population owing to the fact that it is possible to adjust the intensity according to one's sports background [27]. Furthermore, where possible, it is suggested to organise periodic outdoor activities in compliance with the NPIs, such as maintaining social distancing, in the hope of being able to return to normal sports and physical activity.

Funding: This research received no external funding.

Acknowledgments: The authors wish to thank Valerio Giustino for his kind collaboration in this editorial.

Conflicts of Interest: The authors declare no conflict of interest.

\section{References}

1. Vetter, P.; Vu, D.L.; L’Huillier, A.G.; Schibler, M.; Kaiser, L.; Jacquerioz, F. Clinical features of COVID-19. BMJ 2020, 369, m1470. [CrossRef] [PubMed]

2. World Health Organization. Coronavirus Disease 2019 (COVID-19): Situation Report, 52. Available online: https:/ / apps.who. int/iris/handle/10665/331476 (accessed on 30 November 2021).

3. Porcher, S. Response2covid19, a dataset of governments' responses to COVID-19 all around the world. Sci. Data 2020, 7, 423. [CrossRef] [PubMed]

4. Giustino, V.; Parroco, A.M.; Gennaro, A.; Musumeci, G.; Palma, A.; Battaglia, G. Physical Activity Levels and Related Energy Expenditure during COVID-19 Quarantine among the Sicilian Active Population: A Cross-Sectional Online Survey Study. Sustainability 2020, 12, 4356. [CrossRef]

5. Di Stefano, V.; Battaglia, G.; Giustino, V.; Gagliardo, A.; D’Aleo, M.; Giannini, O.; Palma, A.; Brighina, F. Significant reduction of physical activity in patients with neuromuscular disease during COVID-19 pandemic: The long-term consequences of quarantine. J. Neurol. 2020, 268, 20-26. [CrossRef]

6. Haug, N.; Geyrhofer, L.; Londei, A.; Dervic, E.; Desvars-Larrive, A.; Loreto, V.; Pinior, B.; Thurner, S.; Klimek, P. Ranking the effectiveness of worldwide COVID-19 government interventions. Nat. Hum. Behav. 2020, 4, 1303-1312. [CrossRef]

7. Hsiang, S.; Allen, D.; Annan-Phan, S.; Bell, K.; Bolliger, I.; Chong, T.; Druckenmiller, H.; Huang, L.Y.; Hultgren, A.; Krasovich, E.; et al. The effect of large-scale anti-contagion policies on the COVID-19 pandemic. Nature 2020, 584, $262-267$. [CrossRef] [PubMed]

8. Viner, R.M.; Russell, S.J.; Croker, H.; Packer, J.; Ward, J.; Stansfield, C.; Mytton, O.; Bonell, C.; Booy, R. School closure and management practices during coronavirus outbreaks including COVID-19: A rapid systematic review. Lancet Child Adolesc. Health 2020, 4, 397-404. [CrossRef]

9. Auger, K.A.; Shah, S.S.; Richardson, T.; Hartley, D.; Hall, M.; Warniment, A.; Timmons, K.; Bosse, D.; Ferris, S.A.; Brady, P.W.; et al. Association between Statewide School Closure and COVID-19 Incidence and Mortality in the US. JAMA 2020, 324, 859-870. [CrossRef]

10. Donohue, J.M.; Miller, E. COVID-19 and School Closures. JAMA 2020, 324, 845-847. [CrossRef]

11. Watson, A.; Koontz, J.S. Youth sports in the wake of COVID-19: A call for change. Br. J. Sports Med. 2020, 1, 764. [CrossRef]

12. Gjaka, M.; Feka, K.; Bianco, A.; Tishukaj, F.; Giustino, V.; Parroco, A.M.; Palma, A.; Battaglia, G. The Effect of COVID-19 Lockdown Measures on Physical Activity Levels and Sedentary Behaviour in a Relatively Young Population Living in Kosovo. J. Clin. Med. 2021, 10, 763. [CrossRef] [PubMed]

13. Chaput, J.P.; Willumsen, J.; Bull, F.; Chou, R.; Ekelund, U.; Firth, J.; Jago, R.; Ortega, F.B.; Katzmarzyk, P.T. 2020 WHO guidelines on physical activity and sedentary behaviour for children and adolescents aged 5-17 years: Summary of the evidence. Int. J. Behav. Nutr. Phys. Act. 2020, 17, 141. [CrossRef]

14. Ghosh, R.; Dubey, M.J.; Chatterjee, S.; Dubey, S. Impact of COVID -19 on children: Special focus on the psychosocial aspect. Minerva Pediatr. 2020, 72, 226-235. [CrossRef] [PubMed] 
15. McGuine, T.A.; Biese, K.M.; Petrovska, L.; Hetzel, S.J.; Reardon, C.; Kliethermes, S.; Bell, D.R.; Brooks, A.; Watson, A.M. Mental Health, Physical Activity, and Quality of Life of US Adolescent Athletes during COVID-19-Related School Closures and Sport Cancellations: A Study of 13000 Athletes. J. Athl. Train. 2021, 56, 11-19. [CrossRef]

16. Dubé, J.P.; Smith, M.M.; Sherry, S.B.; Hewitt, P.L.; Stewart, S.H. Suicide behaviors during the COVID-19 pandemic: A metaanalysis of 54 studies. Psychiatry Res. 2021, 301, 113998. [CrossRef] [PubMed]

17. Calcaterra, V.; Vandoni, M.; Pellino, V.C.; Cena, H. Special Attention to Diet and Physical Activity in Children and Adolescents with Obesity during the Coronavirus Disease-2019 Pandemic. Front. Pediatr. 2020, 8, 407. [CrossRef]

18. Pagani, L.S.; Fitzpatrick, C.; Barnett, T.A.; Dubow, E. Prospective associations between early childhood television exposure and academic, psychosocial, and physical well-being by middle childhood. Arch. Pediatr. Adolesc. Med. 2010, 164, 425-431. [CrossRef]

19. Guthold, R.; Stevens, G.A.; Riley, L.M.; Bull, F.C. Global trends in insufficient physical activity among adolescents: A pooled analysis of 298 population-based surveys with 1.6 million participants. Lancet Child Adolesc. 2020, 4, 23-35. [CrossRef]

20. Bull, F.C.; Al-Ansari, S.S.; Biddle, S.; Borodulin, K.; Buman, M.P.; Cardon, G.; Carty, C.; Chaput, J.P.; Chastin, S.; Chou, R.; et al. World Health Organization 2020 guidelines on physical activity and sedentary behaviour. Br. J. Sports Med. 2020, 54, 1451-1462. [CrossRef]

21. Trudeau, F.; Laurencelle, L.; Shephard, R.J. Tracking of physical activity from childhood to adulthood. Med. Sci. Sports Exerc. 2004, 36, 1937-1943. [CrossRef] [PubMed]

22. Hills, A.P.; Andersen, L.B.; Byrne, N.M. Physical activity and obesity in children. Br. J. Sports Med. 2011, 45, 866-870. [CrossRef] [PubMed]

23. Battaglia, G.; Giustino, V.; Tabacchi, G.; Alesi, M.; Galassi, C.; Modica, C.; Palma, A.; Bellafiore, M. Effectiveness of a Physical Education Program on the Motor and Pre-literacy Skills of Preschoolers from the Training-To-Health Project: A Focus on Weight Status. Front. Sports Act. Living 2020, 2, 579421. [CrossRef]

24. Battaglia, G.; Giustino, V.; Tabacchi, G.; Lanza, M.; Schena, F.; Biino, V.; Giuriato, M.; Gallotta, M.C.; Guidetti, L.; Baldari, C.; et al. Interrelationship between Age, Gender, and Weight Status on Motor Coordination in Italian Children and Early Adolescents Aged 6-13 Years Old. Front. Pediatr. 2021, 9, 738294. [CrossRef]

25. Rundle, A.G.; Park, Y.; Herbstman, J.B.; Kinsey, E.W.; Wang, Y.C. COVID-19-Related School Closings and Risk of Weight Gain among Children. Obesity (Silver Spring) 2020, 28, 1008-1009. [CrossRef] [PubMed]

26. Guddal, M.H.; Stensland, S.O.; Smastuen, M.C.; Johnsen, M.B.; Zwart, J.A.; Storheim, K. Physical activity and sport participation among adolescents: Associations with mental health in different age groups. Results from the Young-HUNT study: A crosssectional survey. BMJ Open 2019, 9, e028555. [CrossRef] [PubMed]

27. Schoeppe, S.; Alley, S.; Rebar, A.L.; Hayman, M.; Bray, N.A.; Van Lippevelde, W.; Gnam, J.P.; Bachert, P.; Direito, A.; Vandelanotte, C. Apps to improve diet, physical activity and sedentary behaviour in children and adolescents: A review of quality, features and behaviour change techniques. Int. J. Behav. Nutr. Phys. Act. 2017, 14, 83. [CrossRef] 